DS 



\section{CORPUS IURIS}

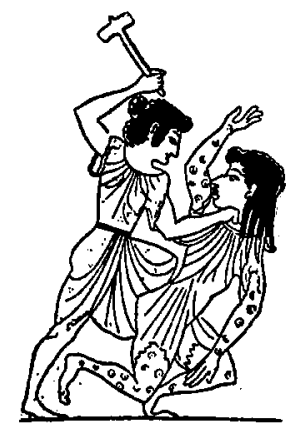

"Das Recht scblagt das Cnrecht"

Antike Vunenzeichnung

Fine Auswahl der Rechtsgrundsätze der Antike. Ubbersetzt und mit dem Urtext herausgegeben von Dr. Rudolf Düll im Ernst Heimeran Verlag 
Ein Band der Tusculum·Bücher.

Umschlag : Kaịer Justínian, der Schōpfer des Corpus luris. Zeitgenössisches Mosaik In San Vitale, Ravenna. VI. Jabrb. 